\title{
SISTEM UJIAN BERBASIS ONLINE
}

\author{
Adhetya Kurniawan ${ }^{1}$, Danny Firman Ocviansyah², Arif Andriyanto ${ }^{3}$ \\ 1,2,3Program Studi Pendidikan Teknik Otomotif \\ Universitas Negeri Semarang \\ Indonesia
}

e-mail: adiet@mail.unnes.ac.id ${ }^{1}$, danny.fo@students.unnes.ac.id², andriarif01@gmail.com³

\begin{abstract}
Abstrak
Penggundulan hutan akibat ekploitasi pohon untuk memenuhi kebutuhan kertas sudah pada kondisi memperihatinkan. Data tahun 2010, 42 juta hektar hutan gundul karena eksploitasi pohon oleh manusia. Oleh sebab itu, dunia pendidikan yang menggunakan kertas dalam media pembelajaran, perangkat pembelajaran, administrasi pendidikan, dan instrumen evaluasi sebaiknya sudah mulai beralih pada sistem nirkertas dalam penyelenggaraan pembelajaran. Pengembangan sistem ujian berbasis google class menjadi alternatif solusi permasalahan penggunaan kertas di dunia pendidikan. Tujuan penelitian ini adalah pengembangan sistem ujian berbasis google class pada mata kuliah fisika teknik dengan jenis soal pilihan ganda. Penelitian ini dikembangkan dengan metode R\&D. Pengembangan sistem ujian setelah melalui uji validasi oleh validator ahli didapatkan hasil bahwa sistem ujian yang dikembangkan valid dengan sekor 3,14 dan layak digunakan dengan sedikit revisi. Penerapan saat ujian mahasiswa memberikan respon positif terhadap sistem ujian dengan google class ini sebesar $84 \%$. Hal ini berarti bahwa media sistem ujian google class ini layak untuk dipakai dalam pembelajaran.
\end{abstract}

\section{Kata kunci: Ujian, google class, Media Pemblajaran}

\begin{abstract}
Deforestation due to the exploitation of trees to meet the needs of paper is in poor condition. The data for 2010, 42 million hectares of deforested forests due to human exploitation of trees. Therefore, the world of education that uses paper in learning media, learning tools, educational administration, and evaluation instruments should have begun to switch to the paper system in organizing learning. Development of the Google Class-based examination system becomes an alternative solution to the problem of paper use in the world of education. The purpose of this research is the development of a google class-based examination system in engineering physics courses with multiple choice questions. This research was developed by the R\&D method. The development of the examination system after going through the validation test by the expert validator shows that the developed test system is valid with a score of 3,14 and is feasible to be used with little revision. The application during the student exams gave a positive response to the Google class exam system by $84 \%$. This means that the google class exam system media is suitable for use in learning.
\end{abstract}

Keywords: Exams, google class, learning media 


\section{PENDAHULUAN}

Media pembelajaran yang disusun dengan baik merupakan alat bantu transfer ilmu dari guru kepada peserta didik yang dapat membantu proses pembelajaran menjadi lebih menarik. Penggunaan media atau alat-alat modern di dalam pembelajaran bukan bermaksud mengganti cara mengajar yang baik, melainkan untuk melengkapi dan membantu para guru dalam menyampaikan materi atau informasi. Dengan menggunakan media diharapkan terjadi interaksi antara guru dengan peserta didik secara maksimal sehingga dapat mencapai hasil belajar yang sesuai dengan tujuan. Sebenarnya tidak ada ketentuan kapan suatu media harus digunakan, tetapi sangat disarankan bagi para guru untuk memilih dan menggunakan media dengan tepat baik menggunakan kertas maupun nirkertas.

Media dengan menggunakan kertas dapat merusak kelestarian lingkungan hutan. Hutan menurut Undang - Undang tentang Kehutanan Nomor 41 tahun 1999 adalah suatu kesatuan ekosistem (ekosistem hutan ini merupakan hubungan timbal balik antara kumpulan populasi binatang maupun tumbuh-tumbuhan yang berada dalam suatu kawasan hutan) berupa hamparan lahan berisi sumber daya alam hayati yang didominasi oleh pepohonan dalam alam lingkungannya yang satu dengan lainnya tidak dapat dipisahkan. Hutan sebagai ekosistem juga dijuluki sebagai paru-paru dunia, karena hutan menggenggam peranan penting dalam kehidupan manusia maupun makhluk lainnya di bumi ini. Sebagai suatu ekosistem, hutan sangat berperan penting dalam segi manapun, salah satunya pohon yang menghasilkan oksigen dan sumber air, sebagai tempat tinggal berbagai flora dan fauna, sebagai pencegah timbulnya pemanasan global, serta bermanfaat sebagai penyeimbang lingkungan.

Zulkifli Hasan pada tahun 2010, sekitar 42 juta hektar hutan indonesia sudah habis dan gundul (Wibowo: 2010). Hal tersebut tentunya sangat memprihatinkan, betapa banyaknya pohon-pohon yang ditebang serta flora maupun fauna yang mati. Kerusakan hutan tentunya dapat mendatangkan kerugian yang sangat besar bagi kehidupan manusia ataupun makhluk lainnya.

Banyak hal yang dapat menyebabkan terjadinya kerusakan hutan pada saat ini, yaitu penebangan liar, kebakaran hutan, dan eksploitasi hutan secara besarbesaran. Salah satu contoh yang menyebabkan manusia melakukan penebangan yaitu tingginya kebutuhan manusia terhadap bahan baku kayu. Salah satunya pengolahan kayu dari pohon untuk pembuatan kertas yang peranannya sangat penting dan tidak bisa lepas dari kehidupan manusia.

Kertas memang sangat diperlukan dalam kehidupan manusia salah satunya sebagai bahan untuk pembuatan uang, pembuatan buku dan tisu yang paling banyak digunakan saat ini. Hampir seluruh kegiatan manusia seperti pendidikan, pekerjaan, komunikasi, kesehatan serta perbankan umumnya sangat membutuhkan kertas. Namun, sebagai manusia haruslah bijak dalam menggunakan kertas serta dianjurkan untuk menghemat penggunaan kertas. Seperti menggunakannya untuk halhal yang penting, tidak boros ataupun membuang-buang kertas untuk hal yang tidak berguna.

Dunia pendidikan terutama di kampus juga memiliki peran penting dalam kebijakan pengelolaan kertas. Hal itu dapat dilakukan dengan mengarahkan seluruh proses pembelajaran dengan budaya nirkertas. Budaya nirkertas dilakukan dapat menurunkan kebutuhan kertas dalam dunia pendidikan yang sangat besar terutama dalam pembuatan perangkat pembelajaran.

Media pembelajaran nirkertas sangat tepat dijadikan sebagai bidang garapan konservasi lingkungan. Pembelajaran $e$ learning, media power point, dan sistem ujian internet maupun online mendorong peningkatan budaya nirkertas. Oleh sebab itu, ujian yang mendukung konservasi lingkungan sebaiknya sudah tidak perlu menggunakan kertas sebagai media ujian. Hal ini dapat diwujudkan salah satunya 
dengan cara ujian dengan bantuan google class. Peserta ujian dapat mengakses google class menggunakan komputer dalam program yang perambah internet explore, google chrome, dan perambah lain.

Google class dapat membantu mengelola ujian dan penilaian dengan baik sampai dengan pensekoran otomatis. Hal ini disebabkan google class mencocokkan jawaban peserta ujian dengan kunci jawaban yang sudah disiapkan oleh pembuat soal sehingga menghemat waktu, pikiran dan terutama tidak memerlukan kertas. Pengelolaan waktu ujian juga dapat diatur otomatis sesuai kebutuhan pembuat soal sehingga saat waktu ujian habis, maka secara otomatis peserta ujian sudah tidak dapat mengerjakan lagi dan sistem terkunci. Oleh sebab itu, penting jika dunia pendidikan mengembangkan sistem ujian berbasis google class untuk medukung kebijakan nirkertas.

\section{METODE}

Pelaksanaan penelitian ini didasarkan pada metode Research \& Development (R\&D). Research and Development adalah metode penelitian yang digunakan untuk menghasilkan dan menguji keefektifan suatu produk (Sugiyono, 2010: 407). Model pengembangan yang dalam penelitian ini terdiri dari 4-D, yang merupakan singkatan Define, Design, Development, dan Dissemination (Thiagarajan dalam Mulyatiningsih, 2014: 194). Define merupakan kegiatan pengumpulan berbagai informasi yang diperlukan (needs assessment) melalui studi literatur dan observasi lapangan untuk membuat produk awal. Design adalah pembuatan awal produk. Develop adalah kegiatan pengembangan produk sehingga dihasilkan produk yang sudah valid. Kegiatan ini meliputi validasi ahli dan uji coba produk. Disseminate adalah kegiatan mempublikasikan produk pengembangan agar dapat digunakan oleh pengguna baik dosen, guru, maupun pihak yang membutuhkan. Namun, dalam penelitian ini hanya akan digunakan sampai tahap develop karena akan dilakukan pada penelitian selanjutnya.

Penelitian ini fokus pada media google classroom. Google classroom adalah aplikasi yang dibuat oleh google yang bertujuan untuk membantu dosen dan mahapeserta didik apabila kedua hal tersebut berhalangan, mengorganisasi kelas serta berkomunikasi dengan mahapeserta didik tanpa harus terikat dengan jadwal kuliah di kelas (Sabran: 2019).

Instrumen pengumpulan data untuk uji kevalidan dan kepraktisan yang disebutkan di atas berupa angket. Angket yang digunakan dalam penelitian ini berbentuk checklist dengan skala 1, 2, 3, dan 4 . Adapun kriteria dari masing-masing skala penilaian yang digunakan adalah sebagai berikut: Angka 4 berarti sangat baik/ sangat setuju; Angka 3 berarti baik/ setuju; Angka 2 berarti cukup baik/ kurang setuju; Angka 1 berarti kurang baik/ tidak setuju.

Perancangan sistem ujian dilakukan dengan membuat google class di laboratorium komputer Jurusan Teknik Mesin. Tahapan pengembangan dilakukan dalam beberapa tahap untuk mempermudah dan memperjelas arah penelitian. Tahapan awal adalah desain Produk, orientasi produk adalah hasil perkembangan teknologi yang dapat dimafaatkan untuk evaluasi pembelajaran yaitu produk sistem ujian berbasis google class yang nirkertas, berkualitas, menarik, dan mudah digunakan. Salnjutnya, validasi desain sistem ujian dilakukan dengan cara meminta pendapat beberapa pakar atau tenaga ahli yang sudah berpengalaman untuk menilai media pembelajaran yang dirancang. Setiap pakar diminta untuk menilai desain, sehingga selanjutnya dapat diketahui kelemahan dan kekuatan desain. Setelah desain produk, divalidasi melalui diskusi dengan pakar dan para ahli lainnya, maka akan dapat diketahui kelemahannya. Kelemahan tersebut selanjutnya dicoba untuk dikurangi dengan cara memperbaiki desain. Kemudian, pengujian dapat dilakukan dengan ekperimen yaitu membandingkan efektivitas dan efesiensi 
sistem kerja lama dengan yang baru pada satu mata kuliah fisika teknik.

Pengujian produk pada sampel yang terbatas menunjukkan bahwa kinerja sistem kerja baru ternyata yang lebih baik dari sistem lama. Perbedaan sangat signifikan, sehingga sistem kerja baru tersebut dapat diberlakukan.Setelah pengujian terhadap produk berhasil, maka selanjutnya produk yang berupa sistem kerja baru tersebut diterapkan dalam kondisi nyata untuk lingkup yang luas yaitu pada mata kuliah di lingkup Prodi Pendidikan Teknik Otomotif UNNES sejumlah 30 mahasiswa. Dalam operasinya sistem kerja baru tersebut, tetap harus dinilai kekurangan atau hambatan yang muncul guna untuk perbaikan lebih lanjut.

Selanjutnya, pengembangan melaui tahapan revisi produk ini dilakukan, apabila dalam perbaikan kondisi nyata terdapat kekurangan. Dalam uji pemakaian, sebaiknya pembuat produk selalu mengevaluasi bagaimana kinerja produk dalam hal ini adalah sistem kerja. Kemudian, tahapan penerapan desain, desain sistem ujian yang sudah dibuat dilakukan penerapan pada mata kuliah di prodi Pendidikan Teknik otomotif UNNES. Setelah data diperoleh maka harus dilakukan analisis data. Hal ini perlu dilakukan untuk memperoleh data penelitian terutama berkaitan dengan variabel penelitian. Kemudian dilanjutkan menyimpulkan dari hasil pengembangan sistem ujian berdasarkan teori maupun pertimbangan praktis terutama tentang kelayakan sistem ujian.

\section{HASIL DAN PEMBAHASAN}

\section{a. Pembuatan Desain}

Pada Tahap ini telah tercapai pembuatan media CMS berbasis google class dengan mengisi data yang ditanyakan saat pertama kali masuk website google class. Sebelum memulai menggunakan google class terlebih dahulu mengakses website google class tersebut, sebagai berikut :
1) Membuat Pertanyaan/Quiz (Create Question)
Untuk membuat pertanyaan pilih create question, ada dua jenis pilihan soal yaitu soal essay dengan jawaban singkat (short answer) dan soal pilihan ganda (multiple choice).

\section{$\equiv$ Google Classroom}
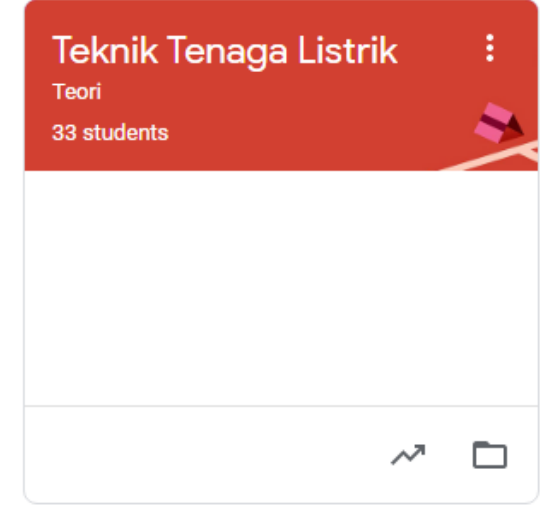

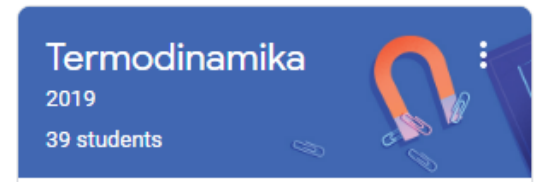

adiet class

Teknik Otomotif

1 student

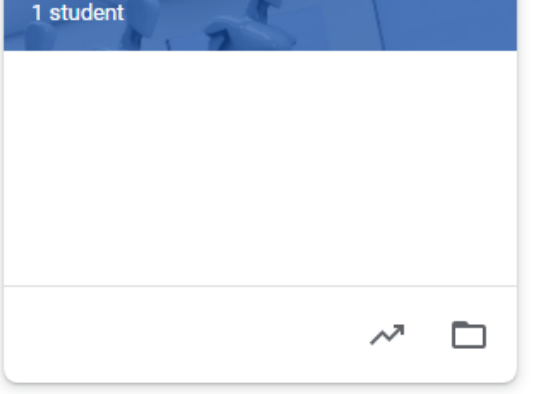

Gambar 1. Tampilan muka google class 


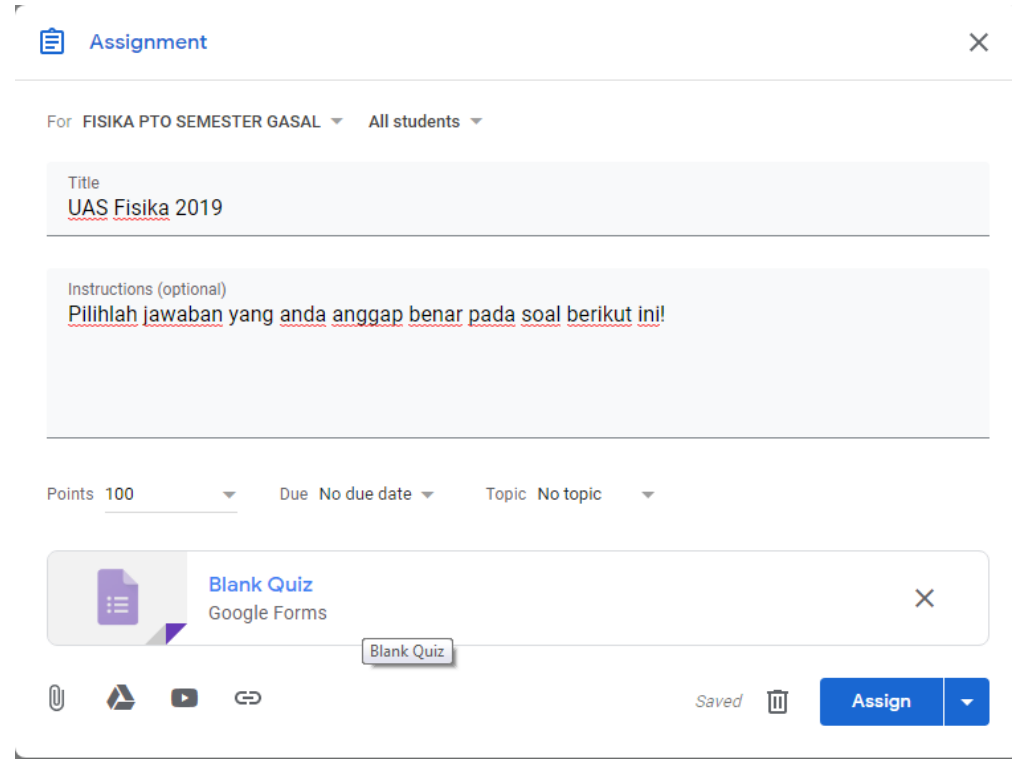

Gambar 2. Membuat quiz/ujian

Proses pengerjaan soal dapat dilihat melalui menu responses, peserta yang sudah mengerjakan dan peserta yang belum mengerjakan soal tersebut beserta jawaban peserta. Setelah tugas terakumulasi, penguji dapat mengoreksi dan memberikan skor atas soal yang telah dijawab.

2) Menilai hasil Kerja/Quiz

Penguji dapat melihat kemajuan pekerjaan peserta ujian dalam google class dan menambahkan komentar atau melakukan pengeditan. Saat ujian selesai, penguji dapat memberikan nilai. Setelah memberi nilai, peserta ujian menerima pemberitahuan melalui email bahwa pekerjaan telah dikoreksi oleh penguji. Pekerjaan peserta ujian dapat dilihat, masuk ke tab tugas peserta kemudian pilih nama peserta yang akan diperiksa tugas/ujiannya.

Untuk memberi nilai, penguji harus memberi batasan sekor maksimal. Secara default google classroom menetapkan sekor 100 , untuk mengubah pilih nilai kemudian tentukan sekor maksimal yang diinginkan. Kemudian jika sekor sudah ditetapkan, pengisian nilai kepada mahasiswa untuk tugas/quiz tersebut dapat dilakukan dengan cara mengisi kolom nilai yang berada di samping nama

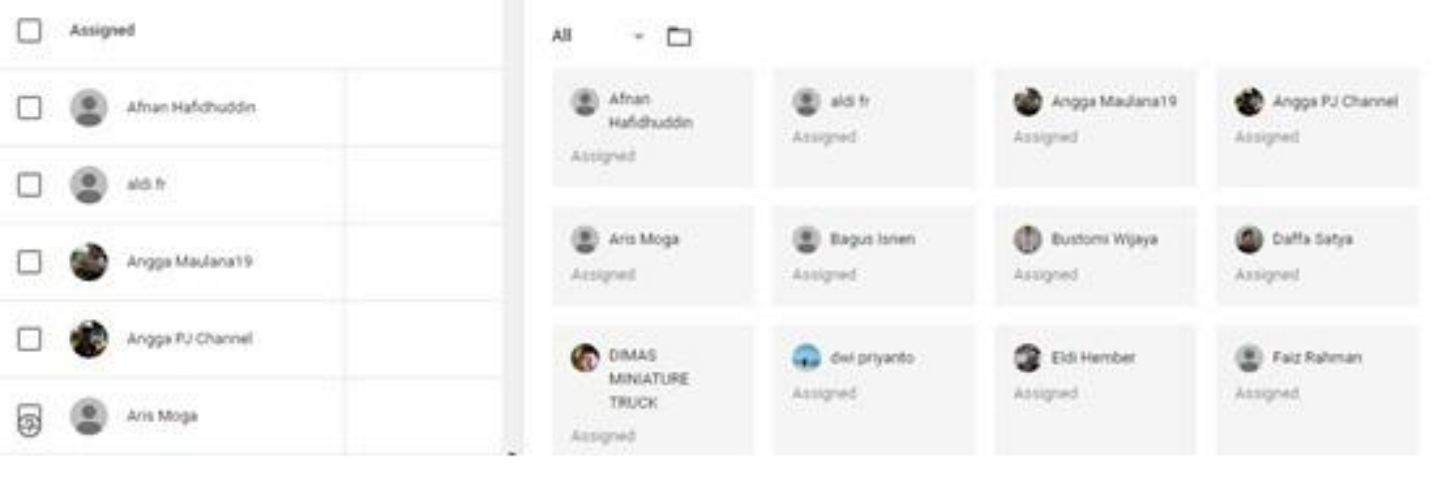

Gambar 3. Memilih tugas/ujian yang akan dikoreksi 
JJTM, Vol. 7 No. 2, Agustus 2019

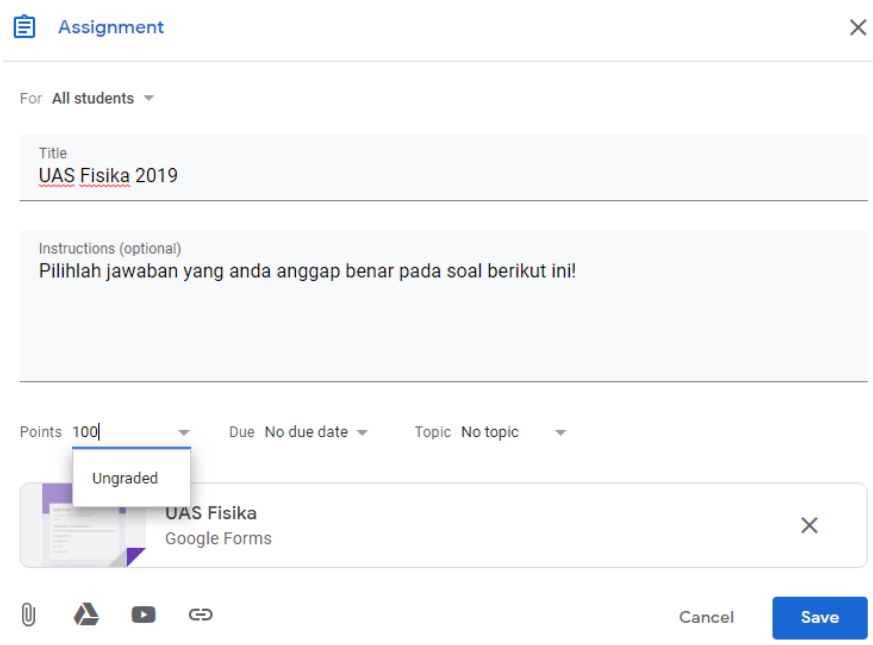

Gambar 4. Mengatur sekor quiz

Kemudahan dalam mengelola hasil ujian juga diberikan oleh google class. Jika ingin mengunduh dan menyimpan nilai tugas sebagai data, klik pada simbol gear kemudian pilih apakah ingin mengunduh satu persatu nilai tugas atau mengunduh semuanya sekaligus.

b. Validasi Desain

Validasi melibatkan dosen teknik mesin Febrian Arif Budiman, M.Pd. sebagai validator, dengan memberikan penilaian untuk menentukan media sistem ujian ini valid untuk dijadikan sistem ujian. Kegiatan validasi sistem ujian ini juga menghasilkan penilaian mengenai kepraktisan sistem ujian. Penilaian kepraktisan ini bertujuan untuk mengetahui apakah sistem ujian google class ini layak digunakan untuk pembelajaran. Sistem ujian dikatakan praktis jika validator menyatakan bahwa sistem ujian ini layak digunakan tanpa revisi atau sedikit revisi. Revisi desain ini berdasarkan saran-saran yang diberikan oleh validator pada saat validasi untuk menghasilkan sistem ujian yang layak digunakan dalam proses pembelajaran.

Dari validasi akan diketahui apakah sistem ujian google class yang sudah dibuat dapat dipakai dengan layak dalam uji coba terbatas. Sistem ujian google class ini dinyatakan valid jika hasil penilaian dari validator. Hasil validasi sistem ujian google class oleh validator disajikan pada tabel 1 sebagai berikut :

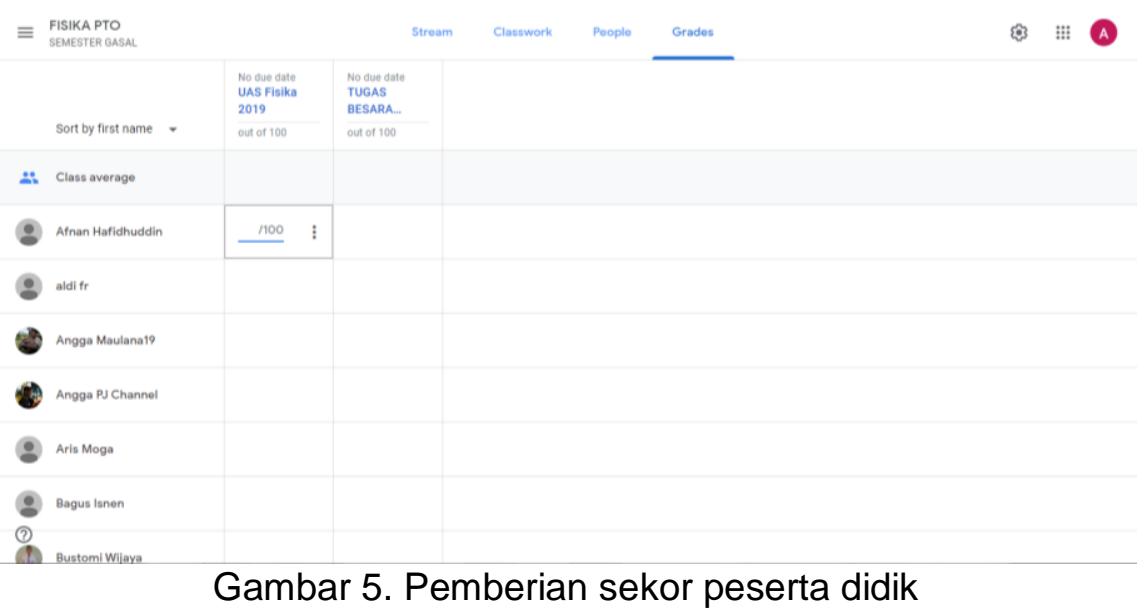


JJTM, Vol. 7 No. 2, Agustus 2019

Tabel 1. Hasil Validasi Media pada Aspek Tampilan

\begin{tabular}{|c|c|c|c|}
\hline No & Komponen & $\begin{array}{l}\text { Sekor dari } \\
\text { Validator }\end{array}$ & $\begin{array}{l}\text { Rata-rata } \\
\text { Sekor }\end{array}$ \\
\hline 1 & Warna & 4 & \multirow[t]{5}{*}{3,5} \\
\hline 2 & Tulisan & 4 & \\
\hline 3 & Tata Bahasa & 3 & \\
\hline 4 & Tata Letak & 4 & \\
\hline 5 & Kegunaan gambar & 3 & \\
\hline
\end{tabular}

Berdasarkan Tabel 1 dan kriteria kevalidan. maka sistem ujian google class yang dikembangkan termasuk dalam kategori "valid" dengan nilai rata-rata total kevalidan sebesar 3,14 . Suatu media dikatakan praktis jika ahli (validator) menyatakan bahwa media berupa sistem ujian google class dapat digunakan tanpa revisi atau sedikit revisi. Berdasarkan hasil penilaian secara umum terhadap media berupa sistem ujian google class, layak digunakan dengan sedikit revisi.

Tabel 2. Hasil Analisis Data Respon Mahasiswa

\begin{tabular}{|l|c|c|c|c|}
\hline \multirow{2}{*}{$\begin{array}{c}\text { Uraian } \\
\text { Pertanyaan }\end{array}$} & \multicolumn{4}{|c|}{ Penilaian/respon Mahasiswa } \\
\cline { 2 - 5 } & \multicolumn{2}{|c|}{ Ya } & \multicolumn{2}{c|}{ Tidak } \\
\cline { 2 - 5 } $\begin{array}{l}\text { Ujian dengan sistem } \\
\text { google class ini menarik }\end{array}$ & 28 & Persentase & Jumlah & Persentase \\
\hline $\begin{array}{l}\text { Petunjuk pengerjaan soal } \\
\text { dalam google class } \\
\text { mudah dipahami }\end{array}$ & 27 & $90 \%$ & 2 & $7 \%$ \\
\hline $\begin{array}{l}\text { Google class } \\
\text { mempermudah } \\
\text { pelaksanaan ujian }\end{array}$ & 26 & $87 \%$ & 4 & $13 \%$ \\
\hline $\begin{array}{l}\text { Google class mudah } \\
\text { dioperasikan saat ujian }\end{array}$ & 22 & $73 \%$ & 8 & $27 \%$ \\
\hline $\begin{array}{l}\text { Akses google class tidak } \\
\text { membutuhkan waktu } \\
\text { lama dalam } \\
\text { menampilkan tiap }\end{array}$ & 23 & $77 \%$ & 7 & $23 \%$ \\
\hline Rata-rata prosentase & & $84 \%$ & & \multicolumn{2}{|c|}{$16 \%$} \\
\hline
\end{tabular}

c. Uji Coba 
Respon mahasiswa terhadap pembelajaran fisika teknik dengan media sistem ujian ini diperoleh dengan menggunakan angket respon mahasiswa. Angket tersebut diberikan setelah berakhirnya proses ujian. Dari data yang diperoleh disajikan secara singkat pada tabel 2 maka dapat dikatakan bahwa respon mahasiswa terhadap sistem ujian google class adalah positif. Hal itu dapat dilihat dari presentasi total yaitu $84 \%$. Respon mahasiswa didukung pendapat Fransiskus (2018) yang menyatakan bahwa Penggunaan Google Classroom berjalan secara optimal.

\section{PENUTUP}

a. Simpulan

1) Pengembangan sistem ujian setelah melalui uji validasi oleh validator ahli didapatkan hasil bahwa sistem ujian yang dikembangkan valid dengan sekor 3,14 serta layak digunakan dengan sedikit revisi.

2) 4.1.2. Penerapan saat ujian mahasiswa memberikan respon positif terhadap sistem ujian dengan google class ini sebesar $86,25 \%$. Hal ini berarti bahwa sistem ujian google class ini layak untuk dipakai dalam pembelajaran.

b. Saran

1) Penelitian ini memerlukan peralatan acess point dengan kualitas baik sehingga dapat digunakan dengan lancar.

2) Sistem ujian ini telah dikembangkan dengan berbagai tahap pengembangan dengan hasil data menunjukkan tingkat kemenarikannya. Namun perlu pengembangan lebih lanjut untuk dapat terus meningkatkan kualitas sistem ujian ini.

\section{DAFTAR PUSTAKA}

Ibal T. Lazuardi S.. 2015. Pengakuan Zulkifli Hasan Soal Skandal Korupsi Hutan. Tempo, https://nasional.tempo.co/read/6562 66/pengakuan-zulkifli-hasan-soal- skandal-korupsi-hutan, diakses pada 17 maret 2018.

Fransiskus Ivan Gunawan dan Stefani Geima Sunarman. 2018. Pengembangan kelas virtual dengan google Classroom dalam keterampilan pemecahan masalah (problem solving) topik vektor pada siswa smk untuk mendukung pembelajaran. Prosiding seminar nasional etnomatnesia Universitas Sanata Dharma halaman 340-348.

Sabran dan Edy Sabara. 2019. Keefektifan Google Classroom sebagai media pembelajaran. Prosiding seminar nasional lembaga penelitian Universitas Negeri Makasar halaman 122-125.

Sugiyono. 2010. Metode Penelitian dan Pengembangan (Reserch and Development/ R\&D). Bandung: Alfabeta.

Undang - Undang Nomor 41 tahun 1999 tentang Kehutanan.

Mulyatiningsih, Endang. 2014. Metode Penelitian Terapan Bidang Pendidikan. Bandung: Alfbeta.

Wibowo. 2010. Menhut: 42 Juta Ha Hutan Indonesia Gundul. Antara News, diakses pada 8 Agustus 2019 dari https://www.antaranews.com/berita/1 70991/menhut-42-juta-ha-hutanindonesia-gun 